\title{
Field Study on Impact of lining water courses on the Distribution and Abundance of Fresh Water Snails in two Egyptian Governorates
}

\author{
Nahed M.M. Ismail, Bayoumy B. Mostafa, Ahmed Abdel Kader, \\ and Ahmed M. Azzam, Hoda M. Abu Taleb
}

\begin{abstract}
Effect of lining water courses on the distribution and abundance of fresh water snails at two Egyptian governorates, Beheria (new reclaimed area) and Giza was studied. Seasonal survey in lined and unlined sites during two successive years was carried out. The collected snail samples from each examined site were placed in plastic aquaria and transferred to the laboratory, where they were sorted out, identified, counted and examined for natural infection. Results revealed that snails were represented in all examined watercourses (lined and unlined) at the two tested habitats by 13 species. During spring, the percentage of live (45\%) snail species was extremely highly significant lower $(p>0.001)$ in lined water bodies compared to the unlined ones (93.5\%) at Beheria. At Giza, the percentage values of live snail species from all lined watercourses (82.6\% and 60.2\%) during winter and spring, respectively was significantly lower $(p>0.05 \& p>0.01)$ than those in unlined ones ( $91.1 \%$ and $79 \%$,respectively). Size frequency distribution of snails collected from the lined and unlined water bodies at Beheria and Giza governorates during all seasons revealed that snail populations were stable and the recruitment of young to adult was continuing for some species, where the recruits were observed with adults.

Thus, the present obtained data support the concept of utilizing environmental modification such as lining of water courses to help in minimizing the population density of certain vector snails and consequently reduce the transmission of snails born diseases.
\end{abstract}

Keywords — lining, fresh water, snails, watercourses.

\section{INTRODUCTION}

$\mathrm{A}_{\mathrm{r}}^{\mathrm{L}}$ LTHOUGH vector snail species require a specific physical environment, the variety of aquatic habitats is almost infinite. Snails have a remarkable capability to

Nahed M.M. Ismail is with the Theodor Bilharz Research Institute, Department of Environmental Research and Medical Malacology, P.O. Box 30, Imbaba, Giza. Egypt.

Bayaumy B. Mostafa is with the Theodor Bilharz Research Institute, Department of Environmental Research and Medical Malacology, P.O. Box 30, Imbaba, Giza. Egypt

Ahmed Abdel Kader is with the Theodor Bilharz Research Institute, Department of Environmental Research and Medical Malacology, P.O. Box 30, Imbaba, Giza. Egypt.

Ahmed. M. Azzam is with the Theodor Bilharz Research Institute, Department of Environmental Research and Medical Malacology, P.O. Box 30, Imbaba, Giza. Egypt.

Hoda, M.Abu Taleb is with the Theodor Bilharz Research Institute, Department of Environmental Research and Medical Malacology, P.O. Box 30, Imbaba, Giza. Egypt. survive long periods (5-8 months) in moist sand or mud (aestivation). Thus, one of the environmental modifications for controlling snail vectors is the lining of all facilities to avoid seepage and minimize aquatic growth. Canal lining with concrete in order to increase flow velocities and reduce aquatic weed growth was also required [1]-[2]. Many authors describe the possible benefits of canal lining which includes: water conservation, no seepage of water, reduction in maintenance cost, minimize the growth of aquatic vegetations and its important role for controlling snails intermediate hosts of parasitic diseases such as schistosomiasis [3]-[9], [2]. It was estimated that after concrete lining, the annual groundwater recharge in the irrigated areas will be reduced by approximately $50 \%$. This saves a substantial amount of water that can be used to extend the irrigation area so more people can benefit from the available irrigation water [8]. Also, as measures of snail control, cement-lining of ditches was the most effective in successful snail control program in Japan and could be adopted ecologically and economically to endemic areas of developing countries [6]. Similarly, the lined and unlined water bodies in some governorates in Egypt were studied by [2] for the distribution and abundance of fresh water snails .The density of all recorded Pulmonate snails (except Bulinus truncatus ) in the lined sites were lower than those of the corresponding ones in the un-lined ones. In contrast, the abundance of Prosobranchia snails (Bellamya unicolor, Melanoides tuberculata, Theodoxus Nilotica, Succinia Cleopatra and Gabbiella senaarensis) was higher in numbers at the lined sites than those in the unlined. Biomphalaria spp were disappeared from the examined lined sites but it presented in only $11.8 \%$ of all unlined ones. On the other hand, many authors stated that soil types of the water bodies substratum may play an important role in the success of mollusciciding operations and may explain the failure in complete eradication of snails by molluscicides in some areas. This depression of the molluscicidal activity may be due to absorption and /or adsorption of some toxic constituents of the molluscicides on mud particles [10]-[16]. 
So lining the water courses by suitable materials is important to improve the mollusciciding methods for snail control [16].

Thus, the present work aims to study the effect of lining water courses on the distribution and abundance of fresh water snails at two Egyptian governorates, Beheria (new reclaimed area) and Giza. In addition the size frequency distribution of these snails were determined in both lined and unlined water bodies.

\section{MATERIALS AND METHODS}

\section{A. Study area}

This study was carried out in different lined and unlined water courses in two governorates (Fig. 1):

1- Beheira Governorate is a coastal governorate in Egypt. Located in the northern part of the country in the Nile Delta, its capital is Damanhur.

Examining sites: Schiek Zaied canal, Seddik Yousif canal, Al-Shouhada village canals, main canals and branches of AlNubaryia city and Nagaa Sultan drain in Janakliz.

2- Giza Governorate is in the center of the country, situated on the west bank of the Nile River opposite Cairo. Its capital is the city of Giza. It includes a stretch of the left bank of the Nile Valley around Giza, and acquired a large stretch of desert, including Bahariya_Oasis.

Examining sites: Kafer Hakkim, Bani Magddull, AlMansuria canal, El-malek idress canal and Kobry el-balah canal.

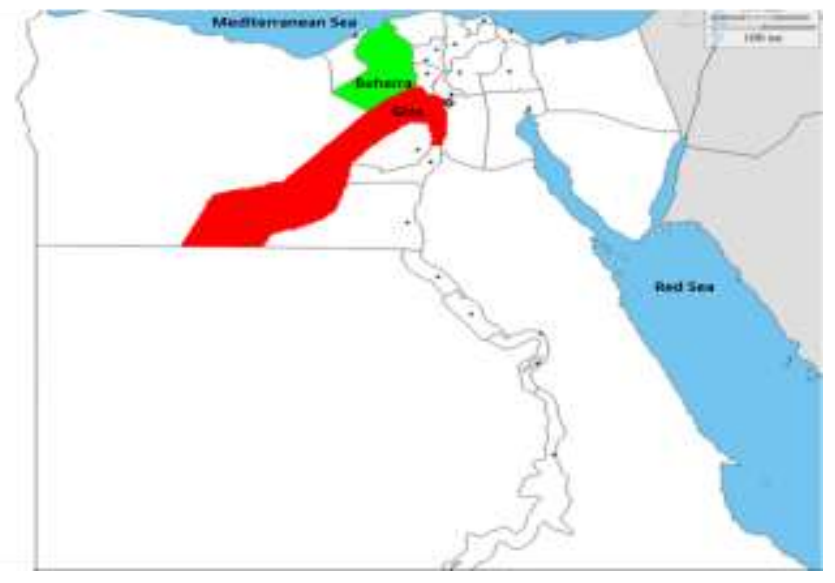

Fig. (1): Map of the study area

\section{B. Ecological Survey}

A regular survey of the banks was carried out in sampling sites during autumn, winter, spring and summer in two successive years (two visits/each season). The survey was done across the lined and unlined canals at the examining sites. Sampling was carried out at fixed sites, $50 \mathrm{~m}$ apart. Samples of snails were collected and their ecological conditions recorded (Field sheets were designed for information for each site of water bodies under study). For each examined site, five consecutive dips using a standard dip net was taken covering several points along the bank
[17]-[18]. The collected snails from each sampling site were placed in a numbered plastic aquaria and transferred to the laboratory. They were sorted out, identified according to [19], counted and examined for natural infection [4]. Living specimens were kept separately from the dead ones. Moreover, the size of each snail (shell width or height) was measured in $\mathrm{mm}$. The size frequency distribution was calculated for each snail species and plotted in graphical forms [20]-[21].

For statistical analysis, data were categorized into four groups; data was performed using SPSS (statistical package social science) program for windows, version 22. Data are presented qualitative variables were expressed by mean \pm standard error. All the parameters characterized by continuous data were subjected to Bartlett's test to meet the homogeneity of variance before conducting analysis of variance (F-test) and Dunnett's t test, they were compared by Mann Whitney test ( $U$-test); qualitative variables were compared by Chi square test $\left(\chi^{2}\right.$ test) or Fisher's exact test from appropriate. Chi-square test was used to compare between the distribution of snails in the lined and unlined watercourses.

\section{RESULTS}

Field survey study reveled that snails collected from lined and unlined sites located at Beheira Governorate were represented in all examined watercourses (lined and unlined) by 13 species (Table I). They belonged to Pulmonate snails (Biomphalaria alexandrina, B. glabrata, Bulinus truncatus, Physa acuta. Helisoma duryi, and Planorbis planorbis) and Prosobranche (Cleopatra bulimoids, Lanistes carinatus, Bellamya unicolor, Melanoides tuberculata, Theodoxus nilotica, Succinia cleopatra and Gabbiella senaarensis). On examining snails, it was observed that dead specimens varied considerably from one seasons to another in the examined lined and unlined water courses. An extremely highly significant difference $(p<0.001)$ was recorded between the dead snails in lined water bodies $(55 \%)$ and unlined ones (6.5\%) during spring (Fig. 2). In contrast, the recorded dead snails during autumn (Fig. 3) was highly significant lower $(p<0.01)$ in lined water bodies $(54.2 \%)$ than the unlined ones $(72.1 \%)$. Non significant difference was found between the dead snails in lined $(48.8 \%, 26 \%)$ and unlined $(57.7 \%$, $28.75 \%$ ) water courses during winter and summer, respectively (Fig. 4 and 5).

The percentage of live snail species collected from different examined lined and unlined sites during autumn was shown in fig. (6). It was found that C. bulimoids $(50 \%)$ was the most abundant species in lined water bodies followed by $M$. tuberculata (21\%) and Ph. acuta (16\%) while $B$. unicolor $(62.7 \%)$ was the higher in unlined ones. However, B. truncatus was represented by only $0.8 \%$ in lined water bodies and completely absent in unlined ones. Also, Biomphalaria spp were absent in both lined and unlined examined water courses. 
TABLE I

MEAN NUMBER OF DIFFERENT SNAIL SPECIES COLLECTED FROM LINED AND UNLINED WATER BODIES IN DIFFERENT EXAMINED SITES IN NEW RECLAIMED AREAS OF BEHARIA GOVERNORATE (NUBARYIA \& CAIRO-ALEXANDRIA ROAD FARMS)

\begin{tabular}{|c|c|c|c|c|c|c|c|c|}
\hline \multirow{2}{*}{$\begin{array}{c}\text { Seasons } \\
\text { Snails spp. }\end{array}$} & \multicolumn{2}{|c|}{ Summer } & \multicolumn{2}{|c|}{ Autumn } & \multicolumn{2}{|c|}{ Winter } & \multicolumn{2}{|c|}{ Spring } \\
\hline & Lined & Unlined & Lined & Unlined & Lined & Unlined & Lined & Unlined \\
\hline L. carinatus & $19.22 \pm 1.7$ & $21.10 \pm 1.38$ & $9.0 \pm 3.0$ & $24.0 \pm 1.0^{* *}$ & $18.0 \pm 6.0^{b}$ & 0 & $24.33 \pm 6.3^{b}$ & 0 \\
\hline B. unicolor & $11.04 \pm 0.5$ & $17.0 \pm 3.0^{* *}$ & $14.40 \pm 1.26^{\mathrm{c}}$ & $17.36 \pm 0.5^{* *}$ & $13.67 \pm 1.86^{\mathrm{c}}$ & $18.0 \pm 0.78^{*}$ & $15.40 \pm 0.5^{\mathrm{c}}$ & 0 \\
\hline C. Bulimoides & $9.17 \pm 0.25$ & $11.0 \pm 0.78^{* *}$ & $8.89 \pm 0.24$ & $11.0 \pm 0^{* *}$ & $7.86 \pm 0.46$ & $7.08 \pm 0.49$ & $10.16 \pm 0.3^{d}$ & $9.45 \pm 0.3$ \\
\hline M. tuberculata & $10.38 \pm 0.23$ & $8.0 \pm 2.01$ & $12.81 \pm 1.07$ & $12.25 \pm 1.2$ & $15.40 \pm 0.85^{\mathrm{e}}$ & $11.33 \pm 0.88^{\mathrm{a}}$ & $12.97 \pm 0.5$ & $11.07 \pm 0.4$ \\
\hline B. glabrata & $6.0 \pm 0.58$ & 0 & 0 & 0 & 0 & 0 & 0 & 0 \\
\hline B. alexandrina & 0 & 0 & 0 & 0 & 0 & 0 & 0 & 0 \\
\hline Ph. acuta & $7.0 \pm 0$ & 0 & $7.40 \pm 00.36^{\mathrm{f}}$ & 0 & $5.76 \pm 0.34$ & $4.22 \pm 0.55^{\mathrm{a}}$ & $6.19 \pm 0.3$ & $4.0 \pm 0.34^{\mathrm{a}}$ \\
\hline H. dyri & $4.28 \pm 0.36$ & $7 \pm 0$ & $5.0 \pm 4.0$ & 0 & $7.70 \pm 0.32$ & 0 & $9.83 \pm 1.14^{\mathrm{g}}$ & 0 \\
\hline Th.niloticus & $4.50 \pm 0.3$ & $4.9 \pm 0.19$ & $4.33 \pm 1.20$ & $5.25 \pm 0.51$ & $7.50 \pm 0.50$ & $3.15 \pm 0.23^{\mathrm{a}}$ & $6.50 \pm 0.5$ & $4.27 \pm 0.14^{\mathrm{a}}$ \\
\hline G. sensariensis & $4.75 \pm 0.20$ & 0 & 0 & 0 & $5.50 \pm 0.50$ & 0 & $4.27 \pm 0.33$ & $2.0 \pm 0^{\mathrm{a}}$ \\
\hline Su. Cleopatra & 0 & $10.50 \pm 1.50$ & $8.50 \pm 0.50$ & 0 & 0 & $2.12 \pm 1.50$ & $3.57 \pm 0.4$ & 0 \\
\hline B. trancatus & 0 & 0 & $6.0 \pm 0$ & 0 & $8.0 \pm 0.71$ & 0 & 0 & 0 \\
\hline P. planorbis & 0 & 0 & 0 & 0 & $4.0 \pm 0$ & 0 & $4.0 \pm 1.41$ & 0 \\
\hline
\end{tabular}

${ }^{* *} p<0.01$ highly significant increase than lined; ${ }^{*} p<0.05$ significant increase than lined; ${ }^{\mathrm{a}} p<0.01$ decrease than lined

${ }^{\mathrm{b}} p<0.01$ spring and winter significant increase than autumn and summer; ${ }^{\mathrm{c}} p<0.01$ spring, winter and autumn significant increase than summer; ${ }^{\mathrm{d}} p<0.01$

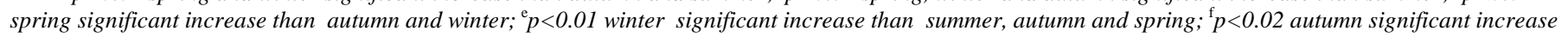
than winter and spring; ${ }^{\mathrm{g}} p<0.01$ spring significant increase than summer, autumn and winter

Results in fig. (7) showed that Ph. acuta was the $1^{\text {st }}$ most abundant snail species recorded in lined water bodies during winter represented by $31.7 \%$ of all collected live snails and M. tuberculata was the $2^{\text {nd }}$ one $(25 \%)$ followed by $H$. duryi (19\%). B. truncatus represented by $3.8 \%$ and disappeared in unlined ones. Biomphalaria spp. and P. planorbis were completely disappeared from lined and unlined snail samples during this season. During spring, snails abundance were trend another pattern in which the Prosobranche snails were the most abundant in the examined lined and unlined water bodies which $T h$. niloticus represented by $52 \%$ in unlined water bodies. While $M$. tuberculata, B. unicolor and $C$. bulimoids were the most abundant snail species collected from lined water courses represented by $32 \%, 31 \%$ and $15.5 \%$ respectively. Whereas, $B$. truncates and Biomphalaria spp. were disappeared from the snail samples of the lined and unlined water bodies during this season (Fig. 8). During summer, M. tuberculata was the most abundant live snail species in lined sites $(85.7 \%)$, while Th. niloticus was the higher in unlined ones, it represented by $59.65 \%$ (Fig. 9).

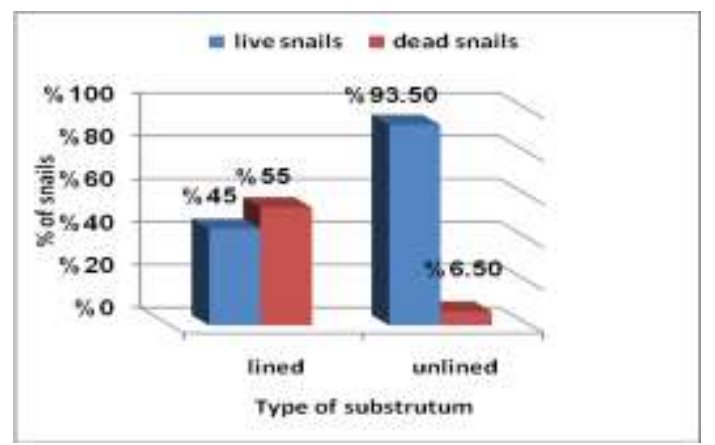

Fig. (2): Percentage of live and dead snails collected from lined and unlined water bodies in different examined sites in new reclaimed areas of Beharia governorate (Nubaryia \& Cairo-Alexandria road farms) during spring.

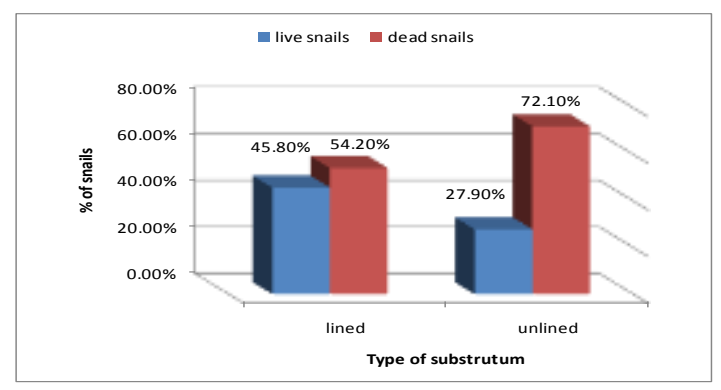

Fig. (3): Percentage of live and dead snails collected from lined and unlined water bodies in different examined sites in new reclaimed areas of Beharia governorate (Nubaryia \& Cairo-Alexandria road farms) during Autumn.

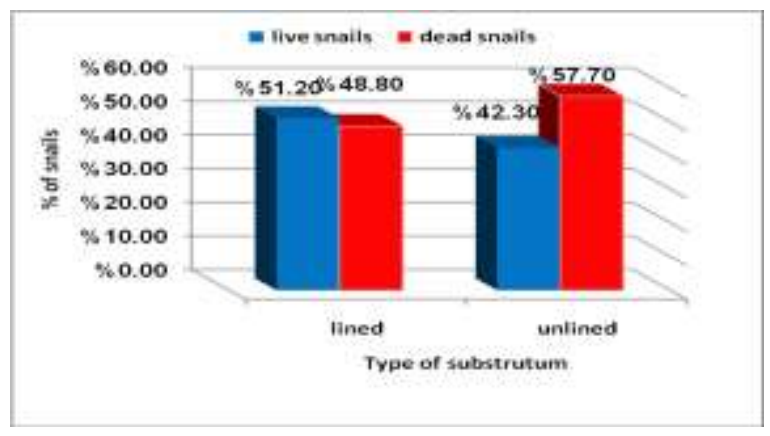

Fig. (4): Percentage of live and dead snails collected from lined and unlined water bodies in different examined sites in new reclaimed areas of Beharia governorate (Nubaryia \& Cairo- Alexandria road farms) during winter. 


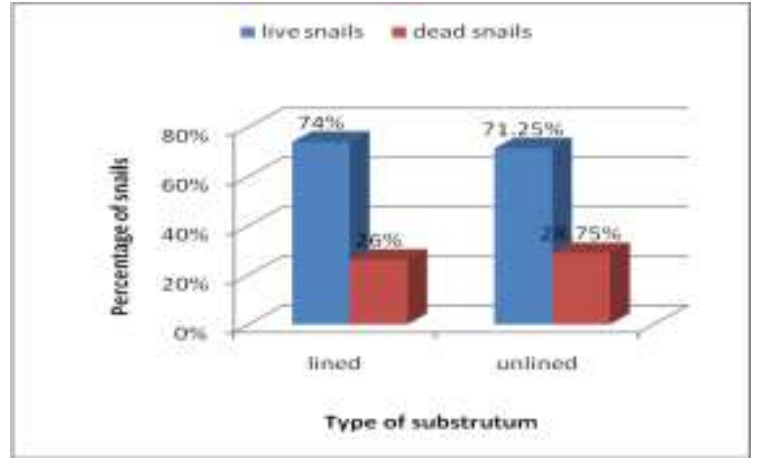

Fig. (5): Percentage of live and dead snails collected from lined and unlined water bodies in different examined sites in new reclaimed areas of Beharia governorate (Nubaryia \& CairoAlexandria road farms) during summer.
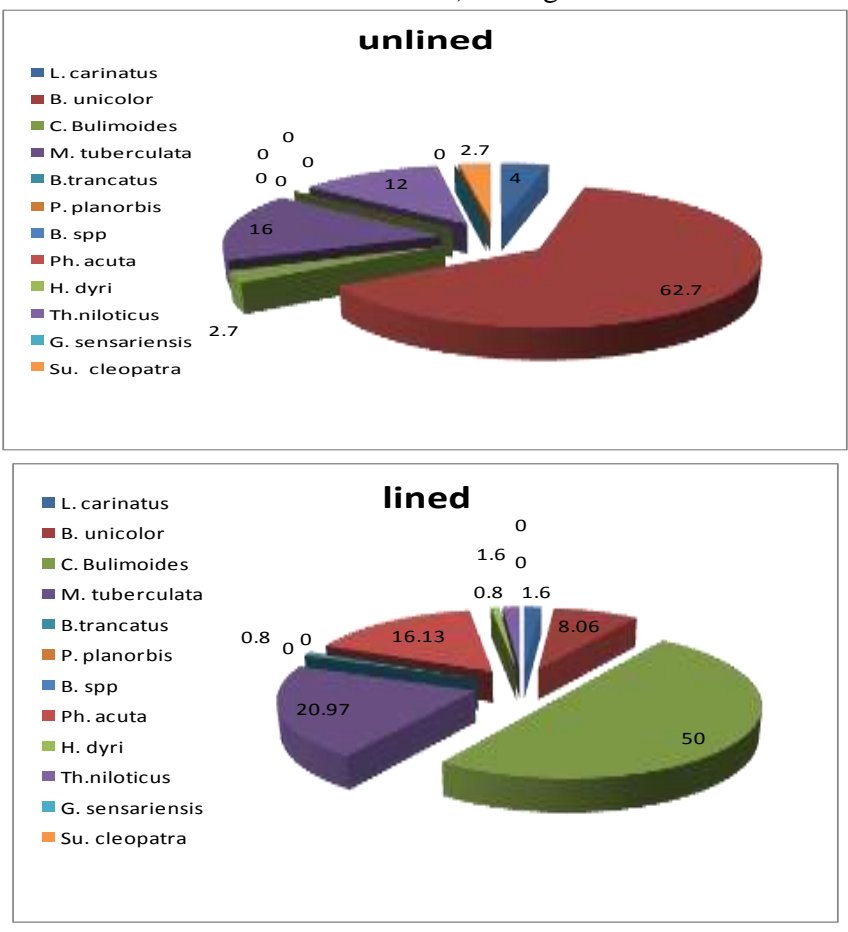

Fig. (6): Percentage of live snails species collected from different examined lined and unlined sites in new reclaimed areas of Beharia governorate (Nubaryia \& Cairo-Alexandria road farms) during Autumn.

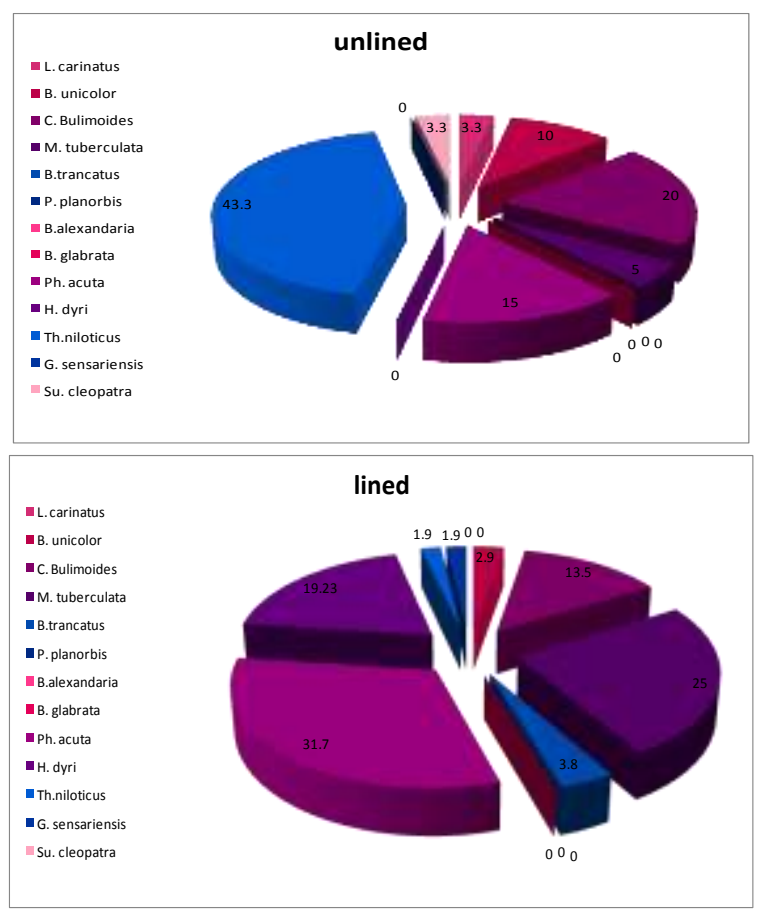

Fig. (7): Percentage of live snail species collected from different examined lined and unlined sites in new reclaimed areas of Beharia governorate (Nubaryia \& Cairo-Alexandria road farms) during winter.

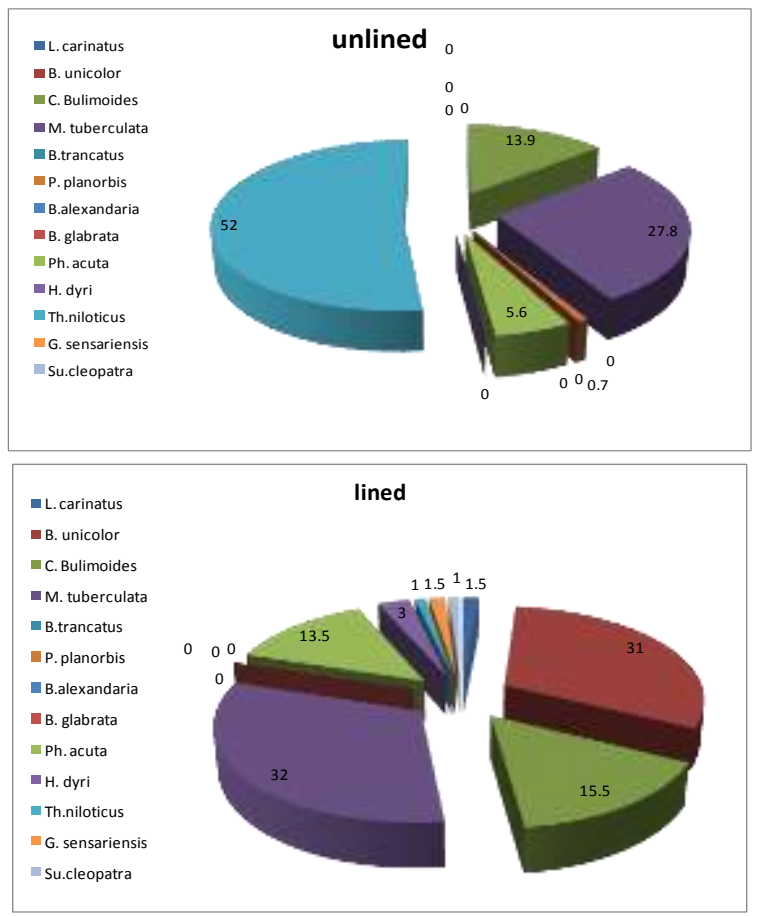

Fig. (8): Percentage of live snail species collected from different examined lined and unlined sites in new reclaimed areas of Beharia governorate (Nubaryia \& Cairo-Alexandria road farms) during Spring. 

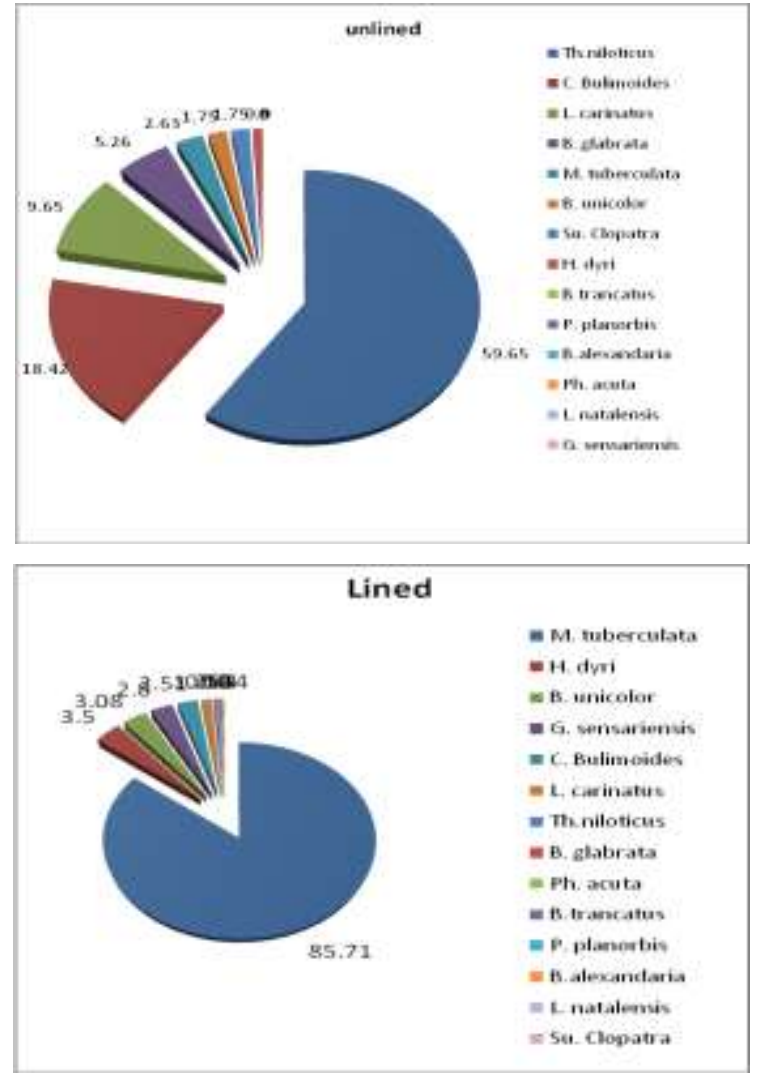

Fig. (9): Percentage of live snails collected from different examined lined and unlined sites in new reclaimed areas of Beharia governorate (Nubaryia \& Cairo-Alexandria road farms) during Summer.

Results of the survey study in lined and unlined water canals at Giza governorate reveled that snails were represented in all examined watercourses (lined and unlined) by 11 species (Table II). They belonged to Pulmonate snails (B. alexandrina, B. glabrata, Ph. acuta. H. duryi, $P$. planorbis $L$. natalensis) and Prosobranchia snails ( $L$. carinatus, B. unicolor, M. tuberculata, S. cleopatra and G. senaarensis). Regarding the comparison between the lined and unlined canals, $P h$. acuta contributed the largest amount of snail species during the three seasons (autumn, winter and spring) which represented by $88.8 \%, 82.5 \%$ and $90.4 \%$, respectively in lined canals and represented by $44.7 \%, 75.5 \%$ and $84.4 \%$ in unlined ones, respectively (Fig. 10, 11,12). However, During summer Ph. acuta was the most abundant live snail species $(78.47 \%)$ collected from unlined sites and M. tuberculata (68\%) was the higher in lined ones (Fig. 13). The percentage value of live snail species from all lined watercourses $(82.6 \%)$ was significantly lower $(p<0.05)$ than those of unlined ones $(91.1 \%)$ during winter (Fig. 14). Also, this percentage was highly significant lower $(p<0.01)$ in lined sites $(60.2 \%)$ compared to the unlined ones $(79 \%)$ during spring (Fig. 15). In this season there was a highly significant increase $(p<0.01)$ of the dead snails in lined water canals (39.8\%) compared to the unlined ones $(21 \%)$. It was found that during summer (Fig. 16), the percentage of live snails was extremely highly significant lower $(p<0.001)$ in lined sites (39\%) compared to those of unlined ones $(73.6 \%)$. On the other hand, the percentage of dead snails was extremely highly significant higher $(p<0.001)$ in lined water bodies (61\%) compared to those of unlined ones (26.4\%). However, during autumn (Fig. 17) the percentage of live snails in both lined $(83.3 \%)$ and unlined(80\%) sites was approximately as the same and was extremely highly significant higher $(p<0.001)$ than the percentage of dead ones in the corresponding sties, lined and unlined $(16.8 \%$ \& 20\%, respectively).

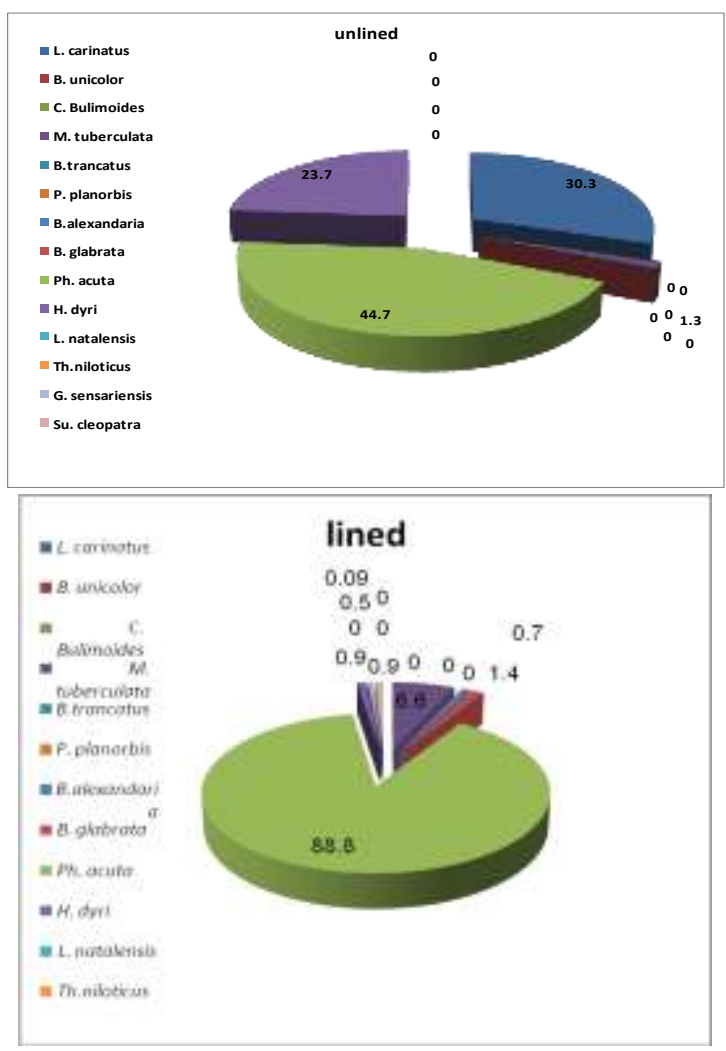

Fig. (10): Percentage of live snails collected from different examined lined and unlined sites in Giza governorate during autumn. 
TABLE II

MEAN NUMBER OF DIFFERENT SNAIL SPECIES COLLECTED FROM LINED AND UNLINED WATER BODIES IN DIFFERENT EXAMINED SITES IN GIZA GOVERNORATE

\begin{tabular}{|c|c|c|c|c|c|c|c|c|}
\hline \multirow{2}{*}{$\begin{array}{c}\text { Seasons } \\
\text { Snails species }\end{array}$} & \multicolumn{2}{|c|}{ Summer } & \multicolumn{2}{|c|}{ Autumn } & \multicolumn{2}{|c|}{ 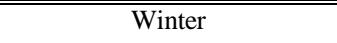 } & \multicolumn{2}{|c|}{ Spring } \\
\hline & Lined & Unlined & Lined & Unlined & Lined & Unlined & Lined & Unlined \\
\hline L. carinatus & $44.0 \pm 0$ & $22.29 \pm 2.4$ & 0 & $26.91 \pm 1.49^{* \pi}$ & 0 & 0 & 0 & 0 \\
\hline $\begin{array}{l}\text { B. alexandariana } \\
\text { B. unicolor }\end{array}$ & $\begin{array}{c}0 \\
20.0 \pm 0\end{array}$ & $\begin{array}{c}0 \\
20.33 \pm 1.05\end{array}$ & $\begin{array}{c}8.43 \pm 0.53^{\#} \\
0\end{array}$ & $\begin{array}{l}0 \\
0\end{array}$ & $\begin{array}{l}0 \\
0\end{array}$ & $\begin{array}{l}0 \\
0\end{array}$ & $\begin{array}{l}0 \\
0\end{array}$ & $\begin{array}{l}0 \\
0\end{array}$ \\
\hline C. Bulimoides & 0 & $10.50 \pm 0.97^{* *}$ & 0 & 0 & 0 & 0 & 0 & 0 \\
\hline M. tuberculata & $12.63 \pm 0.79^{@}$ & $7.67 \pm 1.08$ & $15.81 \pm 0.56^{\mathrm{a}}$ & $11.0 \pm 0$ & 0 & 0 & 0 & 0 \\
\hline B. glabrata & $12.0 \pm 0$ & $16.0 \pm 5.0$ & $18.73 \pm 1.44^{\mathrm{b}}$ & 0 & 0 & 0 & $14.25 \pm 1.03$ & $13.20 \pm 0.58$ \\
\hline Ph. acuta & $7.64 \pm 0.49$ & $18.23 \pm 7.58^{*}$ & $6.97 \pm 0.52^{@}$ & $5.65 \pm 0.49$ & $7.15 \pm 0.09^{\#}$ & $6.15 \pm 0.13$ & $7.65 \pm 0.12$ & $8.63 \pm 0.168^{* *}$ \\
\hline $\begin{array}{l}\text { H. dyri } \\
\text { L.natalensis }\end{array}$ & $\begin{array}{l}0 \\
0\end{array}$ & $\begin{array}{c}5.0 \pm 4.1^{* *} \\
0\end{array}$ & $\begin{array}{c}7.70 \pm 1.04 \\
16.0 \pm 0\end{array}$ & $\begin{array}{c}10.44 \pm 0.81^{*} \\
0\end{array}$ & $\begin{array}{c}7.38 \pm 0.63 \\
10.12 \pm 0.52\end{array}$ & $\begin{array}{c}8.54 \pm 0.28 \\
6.0 \pm 2.0\end{array}$ & $\begin{array}{c}11.24 \pm 0.51^{\$, b} \\
0\end{array}$ & $\begin{array}{c}9.0 \pm 1.03 \\
0\end{array}$ \\
\hline G. sensariensis & 0 & $6.67 \pm 0.49^{* *}$ & $6.40 \pm 0.40^{\#}$ & 0 & 0 & 0 & $6.87 \pm 0.79^{\$}$ & 0 \\
\hline Su. Cleopatra & $5.83 \pm 0.79^{\$}$ & 0 & $9.10 \pm 0.23^{\#}$ & 0 & $9.75 \pm 0.36$ & $10.09 \pm 0.38$ & $10.86 \pm 1.40^{\$, c}$ & 0 \\
\hline
\end{tabular}

${ }^{\#} \mathrm{p}<0.01$ highly significant increase than unlined; ${ }^{\circledR} \mathrm{p}<0.05$ significant increase than unlined; ${ }^{* *} \mathrm{p}<0.01$ highly significant increase than lined; ${ }^{*} \mathrm{p}<0.05$ significant increase than lined; ${ }^{\$} \mathrm{p}<0.05$ significant increase than unlined; ${ }^{a} \mathrm{p}<0.05$ autumn significant increase than summer; ${ }^{b} \mathrm{p}<0.01$ spring significant increase than autumn and winter; ${ }^{c} \mathrm{p}<0.01$ spring significant increase than summer.

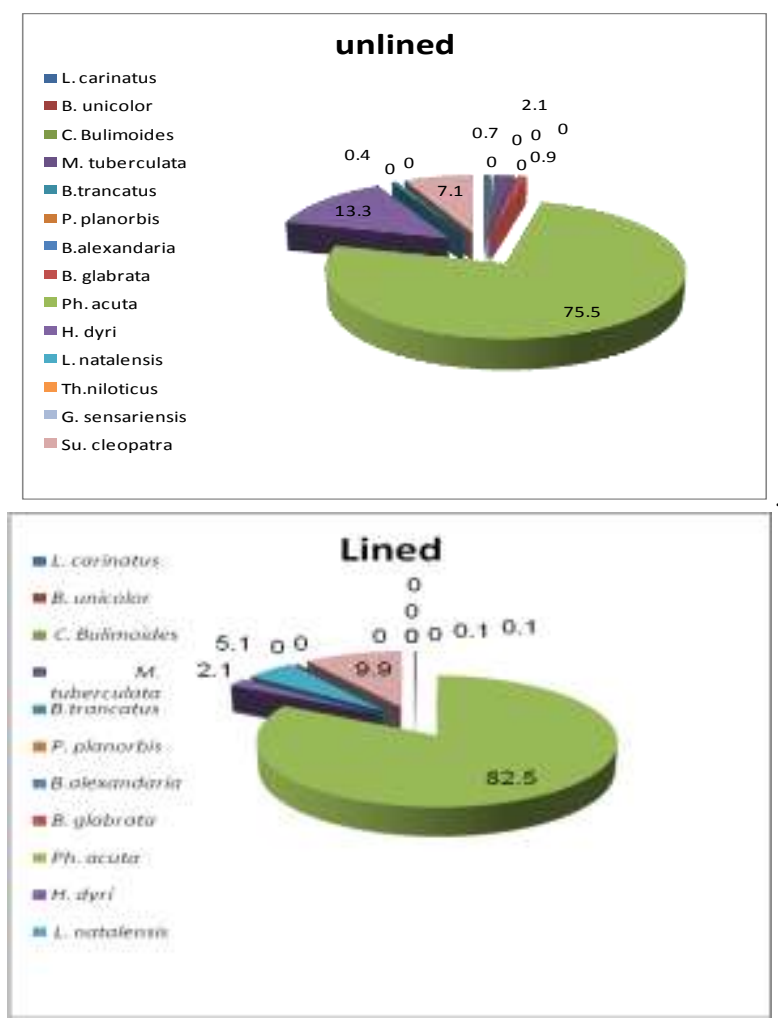

Fig. (11): Percentage of live snails collected from different examined lined and unlined sites in Giza governorate during winter.

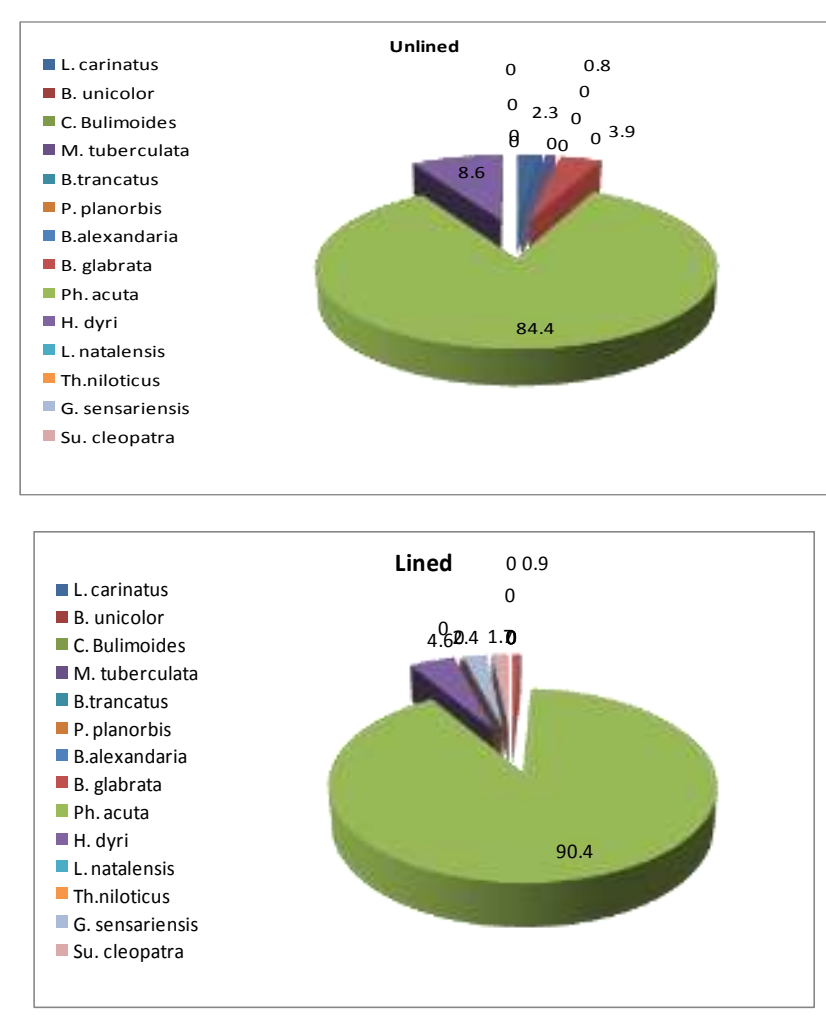

Fig. (12): Percentage of live snails collected from different examined lined and unlined sites in Giza governorate during spring. 

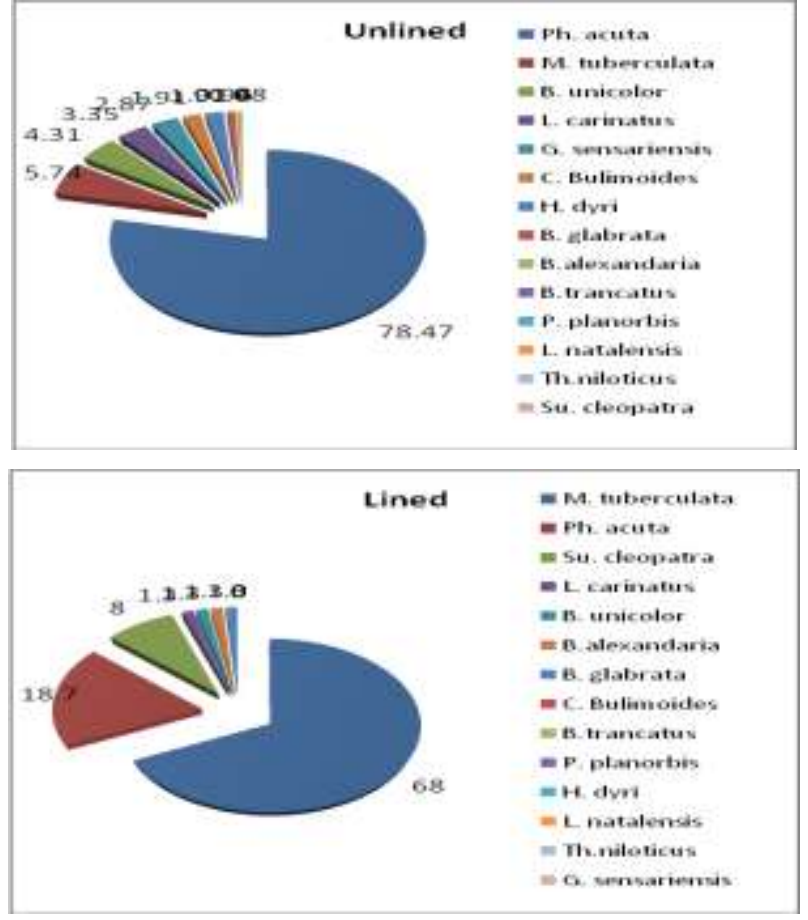

Fig. (13): Percentage of live snails collected from different examined lined and unlined sites in Giza governorate during summer.

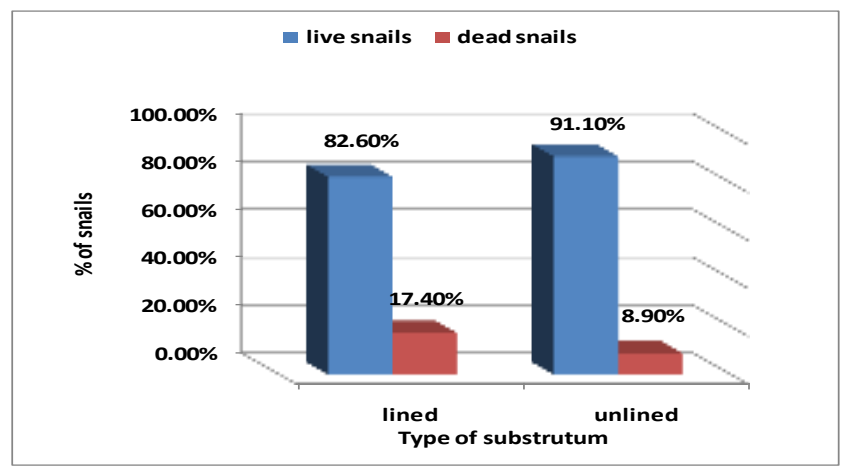

Fig. (14): Percentage of live and dead snails collected from lined and unlined water bodies in different examined sites in Giza governorate during winter.

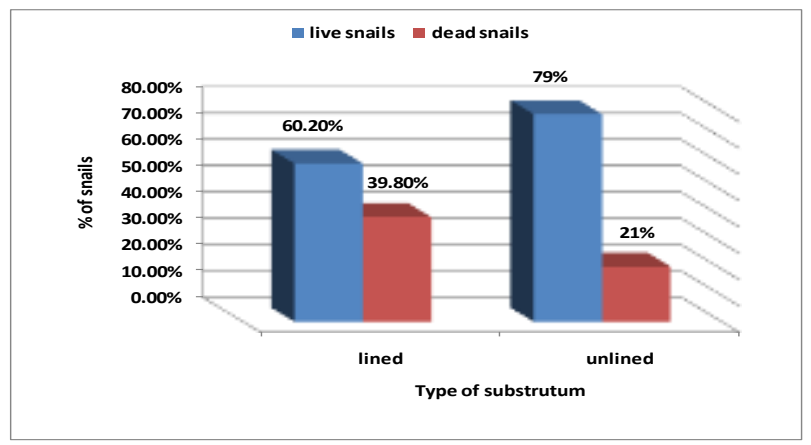

Fig. (15): Percentage of live and dead snails collected from lined and unlined water bodies in different examined sites in Giza governorate during spring.

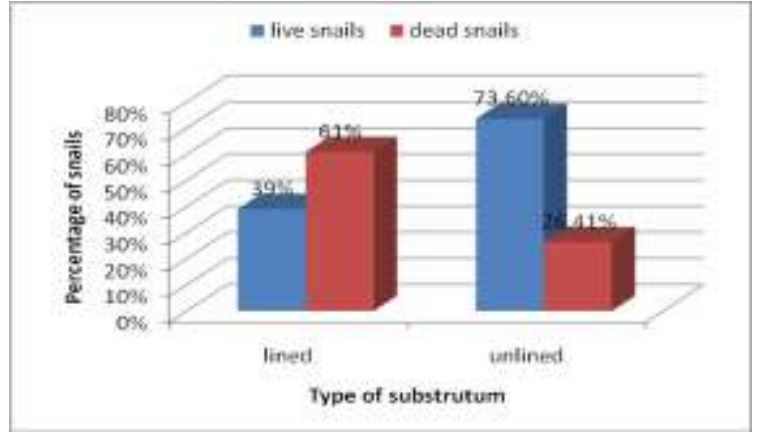

Fig. (16 ): Percentage of live and dead snails collected from lined and unlined water bodies in different examined sites in Giza governorate during summer.

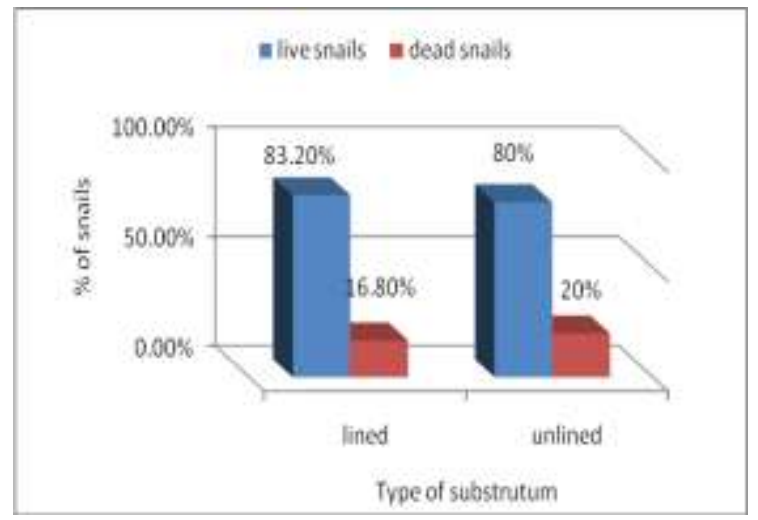

Fig. (17): Percentage of live and dead snails collected from lined and unlined water bodies in different examined sites in Giza governorate during autumn.

Size frequency distribution of some snail species collected from the lined and unlined water bodies at Beheria and Giza Governorates during different seasons is represented in figs. (18) and (19). It was found that during survey, snail populations were stable and the recruitment of young to adult snails was continuing for some species, where the recruits were observed with adults. However, most species showed a higher number of medium size (e.g. Ph. acuta, $M$. tuberculata, C. bulimoids and B. unicolor) in both lined and unlined sites. $H$. duryi showed a lower number of small size, while snails increased in size and number, their trend has shifted towards the large size in both lined and unlined sites. There was no sign of small snails occurrence in case of $B$. glabrata and $B$. alexandrina during autumn, winter and spring seasons and disappear during summer at Giza. Mean while they completely absent during all seasons at Beheria Governorate. 


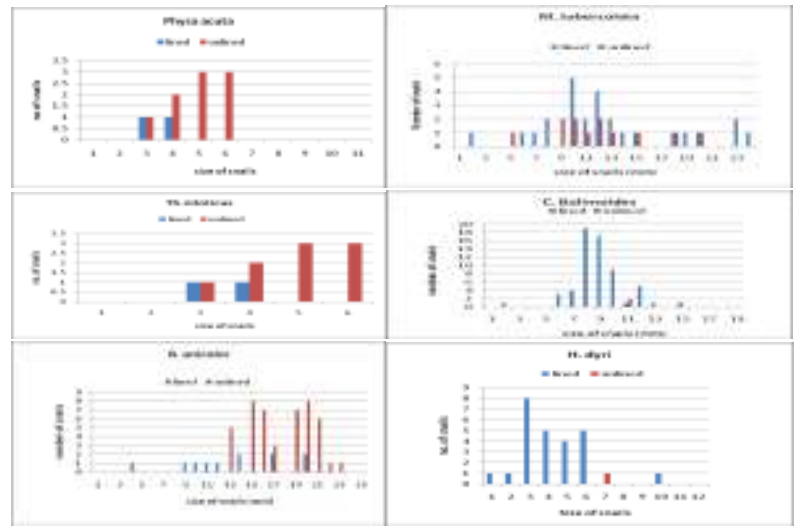

Fig. (18): Size frequency distribution of some snail species collected from lined and unlined water bodies in different examined sites at Beharia governorate.

\section{Discussion}

The results obtained in the present study indicated that the number of collected snail species from lined and unlined sites located at Beheria and Giza governorates varied from one season to another. The survey study in water canals at Beheria governorate showed that snail species were represented in all examined watercourses (lined and unlined) by 13 species. Prosobranche snails (L. carinatus, B. unicolor, M. tuberculata, S. cleopatra and G. senaarensis) were much higher in number and were appeared nearly all over the year in both lined and unlined sites. In contrast, the number of Pulmonate snails (B. alexandrina, B. glabrata, B. truncatus, Ph. acuta. H. duryi, and P. planorbis) in the same sites were much lower which were represented in lined sites by only $B$. spp during summer, B. truncates during autumn and winter, $P$. planorbis in winter and spring. Present results showed that C. bulimoids (50\%) was the most abundant live snail species in lined water bodies during autumn, whereas $M$. tuberculata was the higher ones $(85.7 \%)$ during summer. M. tuberculata, B. unicolor were the most abundant snail species collected from lined water courses during spring. However, Ph. acuta was the $1^{\text {st }}$ snail species recorded in lined water bodies during winter represented by $31.7 \%$ of all collected live snails.

The survey study in water canals located at Giza governorate reveled that snails were represented in all examined watercourses (lined and unlined) by 11 species belonged to both Prosobranchia and Pulmonate snails . Ph. acuta contributed the largest amount of snail species during the three seasons autumn, winter and spring. However, During summer Ph. acuta was the most abundant live snail species $(78.47 \%)$ collected from unlined sites and $M$. tuberculata $(68 \%)$ was the higher in lined ones. The percentage value of live snail species from all lined watercourses $(82.6 \%, 60.2 \%$ and $39 \%)$ was significantly lower $(p<0.05, p<0.01, p<0.001)$ than those of unlined ones $(91.1 \%, 79 \%$ and $73.6 \%)$ during winter, spring and summer, respectively. These results go well with [2] who studied the distribution and abundance of fresh water snails in lined and unlined water bodies in seven Egyptian governorates during

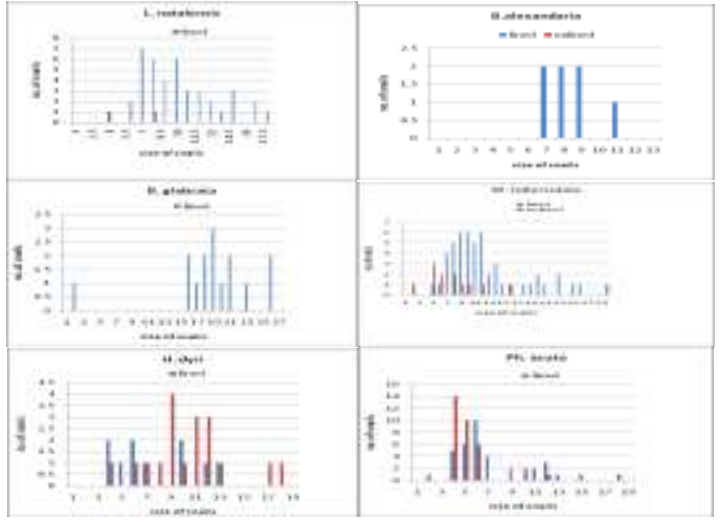

Fig. (19): Size frequency distribution of different snail species collected from lined and unlined water bodies in different examined sites at Giza governorate.

summer season. It was found that the density of all recorded Pulmonate snails (except B. truncatus) in the lined sites were lower than those of the unlined sites. Biomphalaria spp were disappeared from the examined lined sites but it presented in unlined ones with a lower density. L. natalensis was also highly significant lower in the examined lined sites than the unlined ones. However, B. truncatus were found in a higher percentage of lined sites than those of unlined ones. In contrast, the abundance of Prosobranchia snails such as $B$. unicolor, M. tuberculata, Th. nilotica, S. cleopatra and G. senaarensis presented by larger numbers in the lined sites than those of unlined ones. Also, present results confirm those of [20] who found by their survey at World Fish Center in Al-Abbassa, Sharkia governorate (Egypt) that B. truncatus (size: $2-12 \mathrm{~mm}$ ) was the only snail species found in concrete pond. However, they collected a high number of snail species from the unlined inlet and outside irrigation canals. Similarly, [4] studied two newly reclaimed areas in Egypt located west and east of Suez Canal, namely El-Manayef area (All water courses are earthen) and El-Morra area (The water flows into three cement lined branches) for patterns of distribution and population seasonal fluctuation of $B$. alexandrina and $B$. truncatus snails. In El-Morra area, there was a smaller population density of both $B$. alexandrina and $B$. truncatus snails than of El-Manayef area. On the other hand, two cohorts of Bulinus rohlfsi were kept either in water with a mud substratum or in lake water without mud. The growth and survival were significantly greater for the cohort with mud [22]. In Japan, [6] stated that as measures of snail control, cement-lining of ditches was most effective. Moreover, [23] stated that for minimizing the risk of infection of the snail vectors from new water conservation and irrigation schemes is by lining canals with cement and keeping them free from silt and vegetation in which snails can breed. Similar investigation was obtained by [9] who studied the effect of lining water bodies, with cement and plastic compared with mud habitat on the infection of $B$. alexandrina snails by Schistsoma mansoni miracidia. They found that snails infected by miracidia then maintained in aquaria with mud substratum produced a higher significant 
number of cercarial output compared to those maintained in aquaria lined with cement or plastic.

In the present results, the size frequency distribution of snails collected from the lined and unlined water bodies at Beheria and Giza governorates during different seasons was determined. It was found that during survey, snail populations were stable and the recruitment of young to adult snails was continuing for some species, where the recruits were observed with adults. However, most species showed a higher number of medium size (e.g. Ph. acuta, M. tuberculata, C. bulimoids and $B$. unicolor) in both lined and unlined sites. $H$. duryi showed a lower number of small size, which snails increased in size and number and their trend has shifted towards the large size in both lined and unlined sites. There was no sign of small snails occurrence in case of $B$. glabrata and $B$. alexandrina during autumn, winter and spring seasons and disappear during summer at Giza. Meanwhile they completely absent during all seasons at Beheria governorate. These results confirm those of [2] who found that the size frequency distribution of snails collected from lined and unlined water bodies during survey at summer season revealed that, snail populations were stable and the recruitment of young to adult snails was continuing for all species, where the recruits were observed with adults. Also, the present study agree with the obtained ones by [21] who found that during summer and autumn survey in the fish ponds, snail population was stable and recruitment of young to adult snails was continuing for all species. However, during winter and spring, there was no sign of young occurrence, while snails increased in size and number and their trend has shifted towards the large size. Similarly, [20] indicated that snail population was stable and recruitment of young to adult populations was evident in the earthen fish ponds in Egypt.

\section{ACKNOWLEDGMENT}

This study was supported by the Environmental Researches Department, Theodor Bilharz Research Institute, Egypt in the frame of project $84 \mathrm{M}$.

\section{REFERENCES}

[1] S.F. Martin "Health issues related to drainage water management". In "Management of Agriculture Drainage Water Quality, Madramooyoo" CA, Johnston WR, Willardsin LS, (EDS.), International Commission on irrigation and drainage. Food and Agriculture Organization of the United Nation Room, 1997, PP.98-100.

[2] N.M.M. Ismail, " Effect of lined and unlined water bodies on the distribution and abundance of fresh water snails in certain governorates in Egypt. J. Biol. Chem. Environ. Sci., Vol. 4(3) 2009, pp.499-528.

[3] A.J.,Thomson, M.Chimbari, S.K. Chandiwana, B. Ndlela and R.J. Chitsiko "Control of scihstosomiasis. Apractical guide for irrigation development, Report OD-TN 78,TDR Project, 1996, R5937.

[4] F. Yousif, M. El-Emam, A. Abdel "Schistosomiasis in newly reclaimed areas in Egypt. 1-Distribution and population seasonal fluctuation of intermediate host snails" J. Egypt. Soc. Parasitol., vol. 28, 1998, pp.915928.

[5] WHO. "Agricultural development and vector-born diseases Training and Information Materials on Vector Biology and Control." Slide Set Series. Prepared by WHO in collaboration with FAO, UNEP, and UNCHS. PEEM Secretariat, WHO, 1996, Geneva
[6] H. Ohmae, Y. Iwanga and Y. Nara. "Biological characteristics and control of intermediate snail host of Schistosoma japonicum." Parasitol. Inter., vol. 52, 2003, pp. 409-417. https://doi.org/10.1016/S1383-5769(03)00058-8

[7] E. Leigh and G. Fipps "Water loss test results for lateral A before and after lining." Hidalgo County Irrigation District No. 2 , Texas water resources institute, 2006

[8] K. Maijer, K. Boelee, K. Augustjn, and I. Molen van der. "Impacts of concrete lining of irrigation canals on availability of water for domestic use in southern Sir Lanka Agriculture water management" university of twenty publications. Vol. 83(3) ,2006, pp. 243-251.

[9] N.M.M. Ismail, M. N. Sedek and A. M. A. Marei. Effect of lining Water Bodies on the Infection of Biomphalaria alexandrina Snails by Schistosoma mansoni Miracidia. International Conference on Chemical, Environment \& Biological Sciences (CEBS-2014) Sept. 17-18, 2014, Kuala Lumpur, Malaysia, pp. 30-34. http://dx.doi.org/10.15242/IICBE.C914114.

[10] F.A. El-Deeb. "Control of the snails Bulinus truncatus and Biomphalaria alexandarina in Egypt.' M. Sc. Thesis, Pesticides, Fac. Agric., Ain Shams Univ. Egypt., 1986.

[11] K. M. El-Said "The effect of soil and water quality on the chemical behaviour of certain compounds used in controlling the snails of bilharziasis disease in Egypt.” M. Sc. Thesis, Pesticides, Fac. Agric., Ain Shams Univ. Egypt. 1987.

[12] A.A. El-Wakil."Chemical studies of some plants belonging to the families Cheonpodiacae and Zygophyllaceae and their evaluation as molluscicides.” Ph.D. Fac. Sci., Ain Shams Univ. Egypt. 2001.

[13] E. S. Abdel-Hameed. "Chemical studies of the isolated constituents of Furcraea gigantea and Oreopanax reticulatum and its molluscicidal activity." Ph.D. Fac. Sci., Ain Shams Univ. Egypt. 2003.

[14] W.S. Ahmed."Isolation and identification of constituents of some molluscicidal plants of family Araliaceae." Ph.D. Fac. Sci. Cairo Univ. Egypt. 2003.

[15] K. M. El-Said."Efficiency of the plant Anagallis arvensis as a molluscicide against Biomphalaria alexandrina under certain environmental conditions." Egypt. J. Schistosomiasis Infect. Endem. Dis., vol. 26, 2004, pp. 87- 97.

[16] K. M. El-Said, N. M.M. Ismail and M. K. Aly, "Impact of Water Quality and Soils On The molluscicidal Activity of the Plants Agave attenuata and Agave filifera." The New Egypt. J. Med. Vol. 40 (4), 2009, pp. 322332.

[17]A.Ibrahim, F. Yousif and K. El-Hommossany, "Ecological studies on schistosome vector snails in the River Nile at greater Cairo." J. Environ. Sci., vol 11, 2005, pp. 19-37.

[18] F. Yousif, M. Khalil and M. El-Emam, "Evaluation of three common tools in estimating Biomphalaria alexandrina population in irrigation ditches", Egypt. J. Bilh., vol. 14, 1992, pp. 151-158.

[19] A. Ibrahim, H. Bishai and M.T Khalil, "Freshwater mollusks of Egypt". Publication of National Biodiversity Unit, Egyptian Environmental Affairs Agency. No. 10, 1999.

[20] N.M.M. Ismail and A. A. El-Gamal."Correlation between snails and fish in fish ponds of World Fish Center (ICLARM) with special reference to snail vectors of schistosomiasis and fascioliasis." J. Egypt. Soc. Parasitol., vol. 33,2003 , pp. 413-424.

[21]N.M.M. Ismail and F. A. El-Deeb. "Effect of the black carp Mylopharyngodon piceus and the grass carp Ctenopharyngodon idella on the distribution and abundance of snails in Fish ponds." Egypt. J. Aquat. Biol\& Fish., vol. 8, 2004, pp. 175-190.

[22] G. Webbe, K.Y. Chu, and R. Klumpp, "Observations on the growth and population dynamics of Bulinus rohlfsi in an outdoor laboratory at Volta Lake, Ghana." Ann Trop. Med. Parasitol., vol. 79(6),1985, pp. 635-42. https://doi.org/10.1080/00034983.1985.11811971

[23] A. Omer, L. Kassa, W. Tafesse, T. Taye, F. Kebebew and A. Beker "Schistosomiasis." Diploma program for Ethiopian health center team(EPHTI). Haramaya University,2005. 